\title{
Building Human Relations towards Enhancing Service Delivery Effectiveness among Homestay Operators in Malaysia
}

\author{
Siti Salwa Abdul Mutalib ${ }^{1^{*}}$, Abdul Rasid Abdul Razzaq ${ }^{2}$, \& Azman Hasan ${ }^{3}$ \\ ${ }^{1,2 \& 3}$ Universiti Tun Hussein Onn Malaysia, 86400 Johor, MALAYSIA
}

DOI: https://doi.org/10.30880/jtet.2019.11.01.017

Received $11^{\text {th }}$ July 2018; Accepted $14^{\text {th }}$ November 2018; Available online $31^{\text {st }}$ March 2019

\begin{abstract}
Homestay program is an alternative form of tourism products in Malaysia. As it is directly related to customers, it is important to have an effective and an increased customer service level to elevate the satisfactory level as there have been a few grievances reported in past journals about bad service quality of homestays in Malaysia. It is important to maintain a long term relationship with customers to ensure the profitability of homestay operation. To attract and gain new customers is not a cost effective strategy. This study has been carried out to find an effective method in building a good relationship with customers which can enhance customer service delivery effectiveness of homestays in Malaysia. This study applied a qualitative approach by exploring research design. The researchers conducted interviews with five experts in related area purposively. The data was gathered from literature reviews and interview sessions. The theme and categories have been identified before thematic analysis. The result of the study found that there are three main factors to be focused upon, (i) building rapport, (ii) maintaining relationship, and (iii) service recovery. A good relationship is not only applicable to the customers but to the entire stakeholders in order to ensure the success of homestay program in Malaysia.
\end{abstract}

Keywords: homestay; service delivery; human relation; rapport; service recovery

\section{Introduction}

Homestay program is an alternative form of tourism product in Malaysia (Razzaq, Mohamad, Kader, \& Mustafa, 2011). The Malaysian government has encouraged participations from rural area citizens to take part in the homestay program after identifying its potential in attracting foreign tourists (Kayat \& Nur, 2006). This program has created numerous entrepreneurs and job opportunities in rural areas (Effandy, 2011) and at the same time reducing the rural poverty level (Razzaq, et al., 2011).

Service delivery in homestay operations was given less attention from the researchers. This was perceived based on few studies being carried out and very few reports found in the journal regarding this issue (Kunjuraman \& Hussin, 2013). Arifin (2013) and Soh (2015) stated that homestays in Malaysia are not entirely competitive and viable. As referred by previous scholars, they have mentioned on the lack of commitment among the leaders in the community, society involvement problem and insufficient networking in order for the homestays to promote themselves (Soh, 2015). According to Ibrahim \& Razzaq (2010), Malaysian Homestay association still cannot attract more foreign tourist to visit Malaysia. The major issue faced by homestay programs in Malaysia is poor quality of homestay service (Mohd Khodri, 2012) including in the East Coast Economic Region (ECER) (Bhuiyan, Siwar, Ismail, \& Islam, 2011). Mohd Khodri (2012) indicated that there is a gap between quality standard established for service delivery compared to expectation from the customer because homestay operator can only provide the minimum standard. 


\subsection{Service delivery}

Gibson (2011) defined customer service as different things to different persons. Customer service is the process of making the customers becoming satisfied. Meanwhile customer service skill is defined as a crucial behaviour within an employee in order to deliver a good service quality to the customer (Abu-ELSamen, Akroush, Al-Khawaldeh, \& AlShibly, 2011). Customer service is not about how good the product is or a complicated corporate culture but it is about commitment, reliable and loyal employee, and customer satisfaction. Satisfied customer with the service norm will create a positive perception towards the service organization (Brocato, Voorhees, \& Baker, 2012). It is a useful strategy to attract and retain the customers (Gibson, 2011). Also, it is important to satisfy a customer with the service provided as gaining a new customer is five times costlier than keeping a current customer satisfied (Kasari, 2016). Walsh and Gordon (2010) stated that client-oriented service delivery is able to handle the complexity of human need. Meanwhile, Mohd Khodri (2012) said that the ability to give utmost attention towards service delivery may be the key for success.

Queensland Government Official Site (2016) had presented the guidelines to build good relationship with customer: (i) greet customer and approach them nicely, (ii) portray that we understand customer needs and wants, (iii) offer them assistance or share the knowledge in whatever they like and (iv) keep customer updated on what is happening around them. According to Lamberton and Minor-Evans (2014), human relations is not about understanding human behaviour in order to manipulate others. Criteria of good human relations are being positive, real and honest. Practicing effective human relations will make you a better person. If your aim is to build rapport with your customers by involving them in your day-to-day operations, they will give you back ten-fold information and friendship you need in order to succeed. In other word, success in service operation is highly related to service delivery and building relationship. It is important to build a good relationship in order to provide smooth service delivery process to the customer. Thus, this study will identify the influential factor in building human relations that can enhance service delivery effectiveness.

\subsection{Service delivery model}

These studies referred to two models as a basis for knowledge in building human relation in customer service delivery. First is SERVQUAL Model by Valarie Zeithaml, Parasuraman and Leonard Berry (1988). There are ten elements in SERVQUAL Model which are reliability, responsiveness, competence, access, courtesy, communication, credibility, security, knowing the customer and tangible. Meanwhile the other model is Delighting the Customer Model from Panduan Pengurusan Perhubungan Pelanggan (2008) that helps departments and agencies to improve customer relationship management to be more responsive and efficient. There are three elements in that model which are delivery, emotion and physical.

\section{Methodology}

The objective of this study is to find the influential factors in building a good relationship with customers that can enhance service delivery effectiveness of homestay in Malaysia. The research design of this study is exploration of the factors contributing towards the service delivery effectiveness of homestays in Malaysia. This study used qualitative approach by using semi-structured interview method. The interview protocol was prepared prior to the actual interview. Generally, researchers gathered inputs from literature reviews and interview session.

Five respondents who are experts in service delivery and homestays have been purposively selected. The experts have at least 5 years of experience and extensive knowledge in related area. Two respondents came from academic line and another three are from the agencies. The academicians are individuals who have done many researches in homestays and have the experience dealing with MOTAC regarding homestay operation. Meanwhile the agencies are from the organizations handling all the homestay's operation and improvement.

The interviews were recorded and then transcribed by the researchers. The theme and category were established from the interview transcription and thematic analysis was carried out. The data was manually gathered and analysed using pencil and paper method. This paper will provide the guidelines to help all the operators in homestay program to improve service delivery especially in building a good relationship with customers.

\section{Result and Discussions}

The elements selected in this study was from the combination of two sources, (i) literature reviews and the (ii) expert's perspective through the interview session. From the literature review, researchers found that building a good relationship is the key to a good customer service with the customers (Queensland Government Official Site, 2016). Based on findings by Lee (2014), 'The Art of Human Relations' has influences on others by the way they communicate with customers, patients, clients, co-workers, community members, family, and friends. Despite many other benefits that everyone can gain, good human relation can generate powerful and positive impacts on higher levels of customer service. Human relation includes a desire to understand others, their needs and weaknesses, as well as their talents and abilities (Lamberton \& Minor-Evans, 2014). 


\subsection{Human Relation}

The feedback from experts' interview revealed that there are three main elements in building good relations: i) Building rapport, ii) Develop and maintain relationship, and iii) Service recovery. It is important to enhance good service delivery in homestay operation in order to ensure day to day operation smoother and mutual understanding can be accomplished.

\subsection{Building rapport}

Building rapport with customer will make customer more appreciative and help to reel in more business for the owner (Tschohl, 2016). Workstar (2016) said that rapport and trust are important for relationship whether for personal or business matters because they pave the way to understand, appreciate and respect others. According to Kasari (2016) building rapport may contribute to developing trust and a sense of connection with the customers. Kim and Ok (2010) in their study said that rapport consist of two components. First is an enjoyable interaction consisting of six items: (i) enjoyment, (ii) warm, (iii) relating, (iv) harmony, (v) sense of humour and (vi) comfortable. Second component is personal connection consisting of five items: (i) bond, (ii) care, (iii) personal interest, (iv) relationship closeness and (v) looking forward to seeing again.

Based on the feedback from respondents of this study, homestay operators are encouraged to have sense of humour. However, if the operators, by nature, do not have a good sense of humour they can be trained to become at least enjoyable and fun or easy-going person so that tourists or visitors can have an enjoyable stay. One participant said that "we as a trainer always said that you have to have sense of humour, but some of the operator cannot do that because it has to came out from inside. So, we train them to be at least thinking positively and easy going" (R1). Other than that, the operator must show a warm relationship with customer from the beginning and show a positive first impression. This is because in the first five minutes, everything matters to leave permanent mark that can last longer (Ouellette, 2017).

Homestay programs in Malaysia was originally known as family adoption program. There are affectionate feelings like being their own family members with the customer. Sad moments with tears can be witnessed when the host family and the customer are about to be parted. An expert shares the moment "when we let the adopted parent and their adopted child together for the last time, they will shake hand, hug tightly, and start to cry because they feel like they are family" (R2). "When the adopted child wants to go home, the adopted parents are ready the souvenir or food that their adopted child really like during their stay" (R4). It is good to tackle the customer's emotion when the host family give some souvenirs or foods that their customer really like during their stay to take home.

Showing emotion sometimes can be beneficial but sometimes it does not. Bad emotion cannot be shown during interactions with the customers. The operator must know how to control the emotion during interactions with the customer. This is because many operators are facing various problem that can disturb their emotion while delivering the service to the visitor or tourist. Emotion can come from himself/herself like anger, happy, jealous and others. Meanwhile the external factor may come from other people. It includes their spouse who are not supportive in this program and did not gave cooperation, crime case involving family members, family member not behaving properly with the customer, unkind neighbours not giving their cooperation and so on.

\subsection{Maintaining relationship}

In order to get loyal customers, suppliers should focus on building and maintaining good relationship. Managing and maintaining loyal customer can secure supplier's revenue (Rauyruen, 2007). Customer relationship management $(\mathrm{CRM})$ is the proses of building and maintaining the current relationship involving the aspects of acquiring, keeping and growing customers (Shaharudin, Yusof, Elias, \& Mansor 2009). Tseng and Wu (2014) said that CRM is being used to enhance customer loyalty and increase profitability which mainly involved compiling and documenting all the customer and company information. Kotlet and Keller (2009) have given four-step frameworks for CRM marketing: (i) Identify the customer by having wealthy customer database from all sources, (ii) differentiate customer in term of their needs and values towards the company, (iii) interact individually to gather information about their need and build strong relationship, and (iv) formulate customize offers in personalized way. After sales service related to few constant connections with the brand after transaction have been made. Most of the business does not really care about after sales service and it definitely affects customer satisfaction (Shaharudin et al., 2009).

Homestay operators in Malaysia do have record keeping all the numbers of customers staying in their homestays but only a few did a record on customer needs and wants in detail as their own initiative. An expert said that "Record keeping on previous customer's details and their preference is also important. It is good to have track record but unfortunately not all homestay did that properly" (R5). This matter should be reinforced by all homestay operators for them to ensure increased repeat customers. Combination of technologies allows the organization to easily manage the customer information in terms of customer personal detail, customer needs and wants, customer feedbacks and others. It can help to increase homestay operator's knowledge about customer, increase customer satisfaction, save on the cost of service and promotion, and increase profitability. 
The application of the after sales service in homestay operation is a perfect strategy to ensure returning customer. This strategy will make customer feels appreciated and feeling in touch with the operator. Apart from that, operators can use this medium to let the customers know about their current offer or promotion. Some homestay operators are committed to this strategy. They made telephone calls or use smart phone 'whatsapp' application to communicate with their previous customer (also known as adopted child). This strategy can be further leveraged with greetings for every festive days and birthday cards or e-cards. To save money from high charges of telephone call they can use 'whatsapp' or email instead. A statement from an expert said that “... So at least, the customer will still remember Kluang homestay. Next time when the customer wants to go to Kluang, who do you think the customer will think of?" (R4). This strategy has to be applied by the entire homestay operators after customer went back to their homes.

\subsection{Service recovery}

Nusair (2010) in his study said that a strong relationship with customers may avoid any damaging impact of service recovery. Service recovery refers to the activities in which businesses are facing with customer complaint because of service failure. Service recovery strategies are used for the purpose of making the unsatisfied customer become satisfied (Nikbin, Ismail, Marimuthu, \& Jalalkamali, 2010). Based on complaints, handling is part of the profit centre in retaining the profitable customer. In order to resolve the problem, seller must: (i) act fast, (ii) admit mistake but don't be defensive, (iii) show that we understand the problem from the customer point of view, (iv) don't argue with customer, (v) acknowledge the customer feeling and (vi) treated the customer as though they have a valid complaint (Wirtz \& Lovelock, 2016).

Homestay program in Malaysia is a service-based program. Failure in delivering services may happen if the customer is dissatisfied with the services offered. An expert said that "If the service has a breakdown, the service provider must do the service recovery. It happened because the service provided did not meet the customers' expectation" (R3). Customer complaints need to be handled patiently, quickly, and with full commitment. "When customers come with their problem for solution, it means that they are voicing out their grievances to show their loyalty to service providers" (R4). "There really is a need to train appropriate action to solve customer complaint" (R5). If the grievances can be effectively handled, it will alleviate the customer's satisfaction, loyalty and positive news will spread from word of mouth.

\section{Conclusions}

Effective service delivery is not just about giving what customer wants but the ability to give beyond what they need. By building close relationship with customer we can get the idea of the things that they favour. It is very important to obtain customer satisfaction on the service observed. It is also important to retain long term relationship with customers to ensure the profitability of homestay operation. By applying this strategy, organizations may reduce the cost from acquiring new customer. In homestay operation, good relationship should be maintained not only with the customer but all the stakeholders involved in this program because strong supports from them are crucial to ensure the success of this program.

\section{Reference}

Abu-ELSamen, A. A., Akroush, M. N., Al-Khawaldeh, F. M., \& Al-Shibly, M. S. (2011). Towards an integrated model of customer service skills and customer loyalty: The mediating role of customer satisfaction. International Journal of Commerce and Management, 21, 4. 349-380.

Arifin, A. (2013). Kesediaan masyarakat dalam pembangunan program homestay. Malaysia: PhD. Thesis. Retrieved from http://eprints.uthm.edu.my/4170/1/AFIFAH_BINTI_ARIFIN.pdf.

Australia Government Official Site (2017). Manage Customer Relationship: Department of Industry, Innovation and Science $A U$. Retrieved from https:/www.business.gov.au/info/plan-and-start/start-your-business/what-is-customerservice/manage-customer-relationships

Australia Government Official Site (2017). Manage Customer Relationship: Department of Industry, Innovation and Science $A U$, Australia. Retrieved from https://www.business.gov.au/info/plan-and-start/start-your-business/what-iscustomer-service/manage-customer-relationships

Bhuiyan, M. A. H., Siwar, C., Ismail, S. M., \& Islam, R. (2011). The role of home stay for ecotourism development in east coast economic region, American Journal of Applied Sciences, 8, 6. 540-546.

Brocato, E. D., Voorhees, C. M., \& Baker, J. (2012). Understanding the influence of cues from other customers in the service experience: A scale development and validation, Journal of Retailing, 88, 3. 384-398. 
Effandy, N. N. S., (2011). A study of tourist satisfaction using service quality dimensions for homestay ventures in Labuan. Malaysia: PhD. Thesis. Retrieved from http://eprints.ums.edu.my/7150/1/mt0000000239.pd

Ibrahim, Y., \& Razzaq, A. R. A. (2010). Homestay program and rural community development in Malaysia, Journal of Ritsumeikan Social Sciences and Humanities, 2, 1. 7-24.

Kasari, A. (2016). Exploring Rapport Building in B-to-B Sales. Degree. Thesis. Retrieved from Bhttp://www.theseus.fi/bitstream/handle/10024/116728/Kasari_Aleksi_opinnaytetyo.pdf?sequence=1\&isAllowed=y

Kayat, K., \& Nor, N. A. M. (2006). Penglibatan Ahli Komuniti Dalam Program Pembangunan Komuniti: Program Homestay di Kedah. Akademika, 67. 77-102.

Kim, W., \& Ok, C. (2010). Customer orientation of service employees and rapport: Influences on service-outcome variables in full-service restaurants. Journal of Hospitality \& Tourism Research, 34, 1. 34-55.

Kotler, P., \& Keller, L.K., (2009). A Framework for Marketing Management, (4th Eds.). Pearson Prentice Hall.

Kunjuraman, V., \& Hussin, R. (2013). Satisfaction of domestic tourist with the homestay programme in Mesilou Village. Proceedings of the 3rd Regional Conference on Tourism Research. Sabah: Malaysia, 29-31. Retrieved from https://www.researchgate.net/publication/273124284_Satisfaction_of_Domestic_Tourists_With_the__ Homestay_ Programme_in_Mesilou_Village_Kundasang_Sabah

Lamberton, L. and Minor-Evans, L. (2014). Human Relations: Strategy for success. (5th Eds.). New York: McGrawHill.

Lee, A. S. (2014). The art of Human Relations: A Recipe for Success. Simply Put LLC. Retrieved from https://simplyputllc.com/wp/wp-content/uploads/2017/08/The-Art-of-Human-Relations-1.17.pdf

Nikbin, D., Ismail, I., Marimuthu, M., \& Jalalkamali, M. (2010). Perceived justice in service recovery and recovery satisfaction: The moderating role of corporate image. International Journal of Marketing Studies, 2, 2. 47.

Nusair, K. (2010). Examining the relationship among service recovery, affective commitment, calculative commitment, and trust for e-travel retailers. Information Technology \& Tourism, 12, 4. 317-330.

Ouellette, P. (2017). Five Minutes Matter: First Impressions with Mitchell Walker. Georgia College of Tech. Engineering Official Site. Retrieved from https://coe.gatech.edu/news/five-minutes-matter-first-impressions-mitchellwalker

Queensland Government Official Site, (2016). Principles of good customer service. Retrieved from https:/www.business.qld.gov.au/running-business/consumer-laws/customer-service/improving/principles

Rauyruen, P., \& Miller, K. E. (2007). Relationship quality as a predictor of B2B customer loyalty. Journal of business research, 60, 1.21-31.

Razzaq, A. R. A., Mohamad, N. H., Kader, S. S. S. A., \& Mustafa, M. Z. (2013). Developing Human Capital for Rural Community Tourism: Using Experiential Learning Approach. Procedia-Social and Behavioral Sciences, 93, 1. 18351839.

Shaharudin, M. R., Yusof, K. M. M., Elias, S. J., \& Mansor, S. W. (2009). Factors Affecting Customer Satisfaction in After-Sales Service of Malaysian Electronic Business Market. Canadian Social Science, 5, 6. 10-18.

Soh N. Z. N., (2015). Kualiti Kepimpinan Dalam Kalangan Penyelaras Homestay: Perspektif Pengusaha Homestay. Malaysia: $\mathrm{PhD}$. Thesis.

Steinkirchner, S. (2012). 5 Ways to Improve Your Customer Service. Forbes. Retrieved from https://www.forbes.com/sites/sundaysteinkirchner/2012/08/22/5-ways-to-improve-your-customerservice/\#473adc0814bc

Tschohl, J. (2016). Building Rapport with Customers: If you succeed, financial rewards will flow. Global Banking \& Finance Review. Retrieved from https:/www.globalbankingandfinance.com/building-rapport-with-your customers/

Tseng, S. M., \& Wu, P. H. (2014). The impact of customer knowledge and customer relationship management on service quality. International journal of quality and service sciences, 6, 1. 77-96.

Wirtz, J., \& Lovelock, C. (2016). Complaint Handling and Service Recovery. World Scientific Publishing Co. Pte. Ltd. Retrieved from https://nscpolteksby.ac.id/ebook/files/Ebook/Business Administration/Customer

Workstar (2016). The Customer Experience Game Changer - Empathy \& Rapport: A crucial capability in today's social media centric market. Retrieved from http://cdn2.hubspot.net/hubfs/403016/white_papers/Empathy_and_rapport21DecUpdate.pdf?t=1455244392 
Mohd Khodri, A. F. (2012). Case study: Measuring service quality of homestay in Malacca using SERVQUAL matrix. In Zainal, A., Radzi, S. M., Hashim, R., Chik, C. T., \& Abu, R. (Eds.), Current Issues in Hospitality and Tourism: Research and Innovations, (147-152). Malaysia: CRC Press.

Walsh, K., \& Gordon, J. R. (2010). Understanding professional service delivery. International Journal of Quality and Service Sciences, 2, 2. 217-238.

Failter Ireland (2013). How to Provide Customer Service Excellence: Business Tools. Dublin: Failter Ireland. Retrieved from http://www.failteireland.ie/FailteIreland/media/WebsiteStructure/Documents/2_Develop_Your _Business/1_StartGrow_Your_Business/How_to_Provide_Customer_Service_Excellence.pdf 